\title{
Sailing the Archipelago in a boat of rhymes
}

\author{
Pantun in the Malay world
}

\author{
MUHAMMAD HAJI SALLEH
}

\begin{abstract}
The extremely popular poetic form from Insular Southeast Asia, the pantun, travelled from its unknown source throughout the Malay Archipelago, first in Malay, then in the languages of Southeast Asia. In the ports and states where they were received, local colour, other idiosyncrasies, references, and linguistic characteristics have been added, and in fact, special forms with special names developed. This basic form is known, composed, and loved in at least 40 dialects of Malay, and 35 non-Malay languages, in the Peninsula and many of the islands of Malaysia and Indonesia. It spread through trade routes, ports, and also via diasporas and colonial economic projects which caused numerous peoples to move, who in turn brought the pantun along with them. It is now the most dynamic single literary form and has the longest history.

KEYWORDS

Diaspora, pantun, poetry, trade routes, early kingdoms of Nusantara.
\end{abstract}

\section{INTRODUCTION}

Pantuns, versatile four-line poems from Malaysia, Brunei, Indonesia, Singapore, and Thailand has caught the imagination of many collectors, scholars, translators, and literary historians. Among the earliest one finds Hans Overbeck, a German collector and company manager, and R.J. Wilkinson and R.O. Winstedt, both British colonial scholar-administrators. They were later followed by Harun Mat Piah (1989), François-René Daillie (2002), Georges

MUHAMMAD HAJI SALLEH is a poet, critic, editor, and translator in Malay and English. He is a fellow with the Centre for Policy Research and International Studies, Universiti Sains Malaysia, Penang and has published twelve collections of poetry and thirty-odd books of criticism, translation, and anthologies. Among his major poetry collections in Malay are Perjalanan Si Tenggang II, Sajak-sajak Sejarah Melayu, and Setitik Darah di Bilik Bundar; while in English, they include Time and Its People, Beyond the Archipelago, and Rowing Down Two Rivers. Among his critical works are Romance and Laughter in the Archipelago, Menyeberang Sejarah, Yang Empunya Ceritera: the Mind of the Malay Author. His latest works of translation are The Epic of Hang Tuah and his own Malay Literary Poetics. Muhammad Haji Salleh may be contacted at: mhs0042@gmail.com.

(C) 2011 Faculty of Humanities, University of Indonesia 
Voisset (1997), and Muhammad Haji Salleh (2000). Yet for now the questions of their origin, the magic of their attraction, the relation of the first two lines and the next two still remain unsolved, and will for some time continue to be topics of literary debate.

To date, we have yet to identify all the pantun variations in the Archipelago, but a study done by Muhammad Haji Salleh and Bazrul Bahaman (1999) has found them, among others, in the 40 Malay dialects of several areas. ${ }^{1}$ In the following areas, about 35 non-Malay languages also have pantuns or closely related poetic forms: Kadazan, Kedayan, Bidayuh, Iban, Bajau, Bisaya, Melanau in Borneo/Kalimantan. In East Nusa Tenggara: Timor, Larantuka, Bima, Banda, Flores, Sumbawa, Kaili, Tanemperar, and Tetun. In Sulawesi: Sangihe-Talaud, Minahasa, Gorontalo, Toraja, Makassar, Bugis, while in Sumatra: Aceh, Gayo, Angkola/Mandailing, Simalungun, Pakpak, Lampung, Nias, and Serawai. In Java: throughout the Javanese-speaking region, in Sunda, Madura, Bali, and Lombok. In Javanese they are known as parikan, in Sundanese sisindiran or susualan, in Bali, wewangsalan, while the Achehnese call them rejong or boligoni. In the Toraja language they are known as londe, in Gorontalo as pantungi, but when rendered in Malay they go under the designation lohidu. They are called dolo or dolo-dolo in Flores and kalang among the Buginese. Among the Pakpak they are called mpama, in Simalungun, umpasa in Mandailing and Toba, ende-ende while in Lampung their name is segata or adi-adi. Meanwhile in almost all the Malay variants they are known as pantun, panton, or panthong.

\section{THE PANTUN JOURNEY}

For the moment, the best approach to study the spread of pantuns (see Figure 1) would be to sketch the general routes of their journeys, along the routes of the languages and also the spheres of influence of the kingdoms and their trading centers. If we start with West Kalimantan, the so-called motherland of the Malays and refer to Alexander's (2007) description of a shared MalayDayak, muar wanyek, we find that pantuns belong to both the Dayak and Malay communities around Sintang. Compare the example he gives, first in Sambas Malay.

Bukan kacang sembarang kacang Kacang melilit di tappi mentare Bukan datang sembarang datang. Datang nambusek sanak saudare.
These are no mere beans, their tendrils wind around the sun; This visit is not meant be unseen; It's to gather relatives and everyone.

1 Pantuns are found in Pattani, Kelantan/Terengganu, Pahang, Johor/Melaka, Negeri Sembilan, Selangor/Perak, Kedah/Perlis/Pulau Pinang, Sarawak, Sabah, Brunei, Ketapang, Sambas, Sintang, Banjar, Tanjungpura, Kutai, Betawi, Bangka Belitung, Jambi, Palembang, Riau, Kerinchi, Minangkabau, Rawa, Langkat, Bangkahulu, Deli, Siak, Ambon, Kupang, Larantuka, Manado, Ternate, Bacan, Banda, and Makassar. 
Which he compares with the mantra used for climbing trees among the Dayak Desa of Sintang. ${ }^{2}$
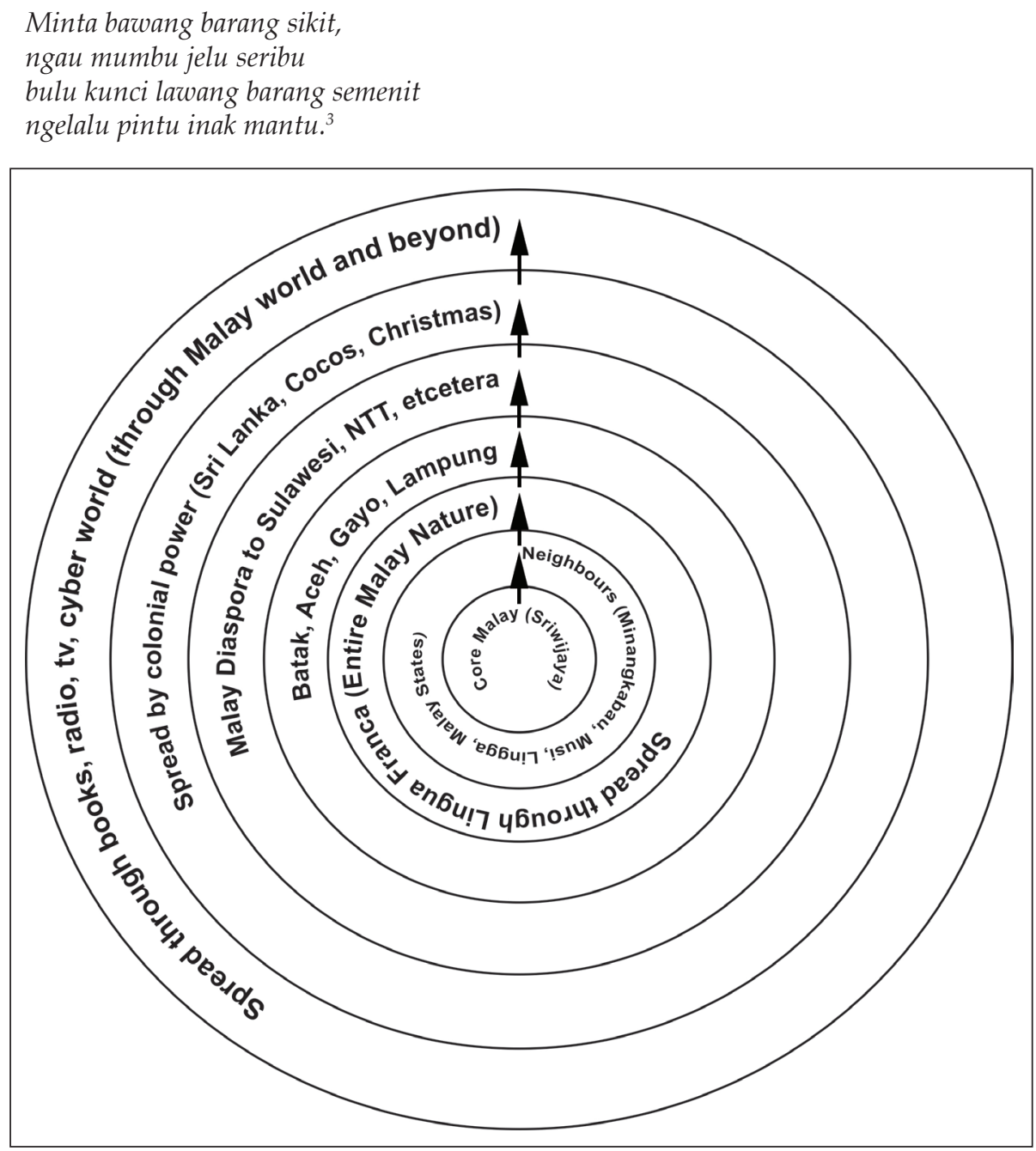

Figure 1. The spread of the pantun form.

While they crossed borders and seas, pantuns also crossed over from its basic function as games and charades for entertainment, to proverbs, metaphors and maxims (perumpamaan), to children's songs, and vehicles of and for love. Besides that adat laws, past wisdom, and traditional laws are sometimes framed within pantuns' easily recalled quatrains. Thus, pantuns, which naturally suited the way of thinking of the Malays, their breath and easy life style, became the main vehicles of their emotions and ideas and of

2 This set of similarities hides other fundamental ones, for example, that nature presents sympathetic symbols and images to ponder upon and to use them as instruments of thought and expression.

3 For this pantun no English translation is available. 
their creative imagination. There is a celebration of the free use of words and naughty teasing and even of criticism of seniors, albeit in hidden terms and allusions.

When Srivijaya became the central power in the southeast of Sumatra from the seventh to thirteenth century and wielded its influence over a vast region in Southeast Asia, the Malay language had become the language of Hinduism and Buddhism (and later of Islam). Malay was easily adopted as the lingua franca as it had been present in the islands for centuries and, in different dialects serviced different groups of islands and communities. ${ }^{4}$

THE SPREAD OF PANTUNS

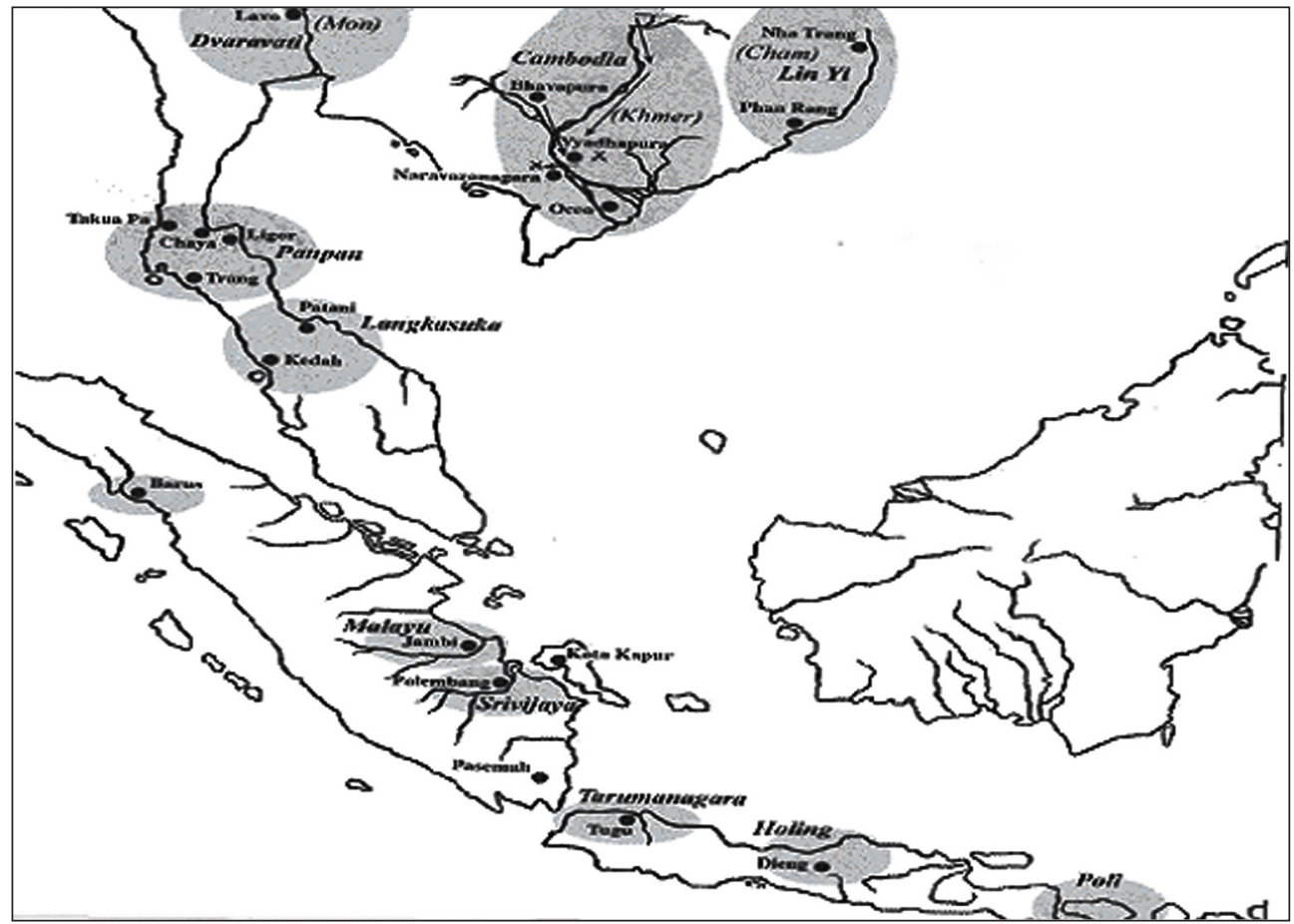

Map 1. Early kingdoms in the Indonesian Archipelago and the Malay Peninsula in the seventh century (Munoz 2006: 111).

On the island of Sumatra and in the Malay Peninsula archeologists have found ruins in Barus, Padang Lawas, Muara Takus, Pagarruyung, Jambi, Palembang,

4 There are, among others, Melayu Ambon (around the Moluccas), Melayu Kupang (around Kupang [Timor] and in East Nusa Tenggara, Melayu Manado) in north Celebes, Melayu Ternate (used in Ternate and Northern Moluccas), Melayu Bacan (in the island of Bacan and Northern Moluccas), Melayu Banda (spoken in the Island of Banda and Moluccas), Melayu Larantuka (in the city of Larantuka, Nusa Tenggara Timur), Melayu Makassar ( in Makassar city), Melayu Betawi (in Jakarta, but versions of it are now used all over Indonesia), Melayu Peranakan (used among the Chinese-Indonesians), Melayu Papua (in Papua), Melayu Sarawak, Melayu Sabah, Melayu Brunei, besides the scores of others that grew up with the different communities to service their own community alone, for example Kelantanese, Kedah, Perak, Pahang, and Malacca/Johor. 
Tanah Abang, Kota Kapur, Pasemah, and Jepara; Lembah Bujang and Cherok Tok Kun, all witnesses of the cities, hinterlands, and kingdoms of pre-classical times (see Map 1). From the seventh century onward, the picture changed a little. Srivijaya was on the rise and polities changed. It was gathering place for traders, scholars, and priests and from the Palembang-Malayu centre the power of the kingdom spread to Tanah Abang and Pasemah in the south. In Java, the famous ones are in western part of the island - Banten, Girang Tand, in the centre of the island, Kedu, Borobudur and Prambanan. On the Peninsula there were Takua Pa, Trang, Patani, Kedah, Chaya, Ligor, Singgora, Patani, Kedah, and in the east Pekan (see Map 2). Far to the north is Lavo and Indrapura, in what is now Thailand and Cambodia. This is indeed a large area of political and cultural influence.

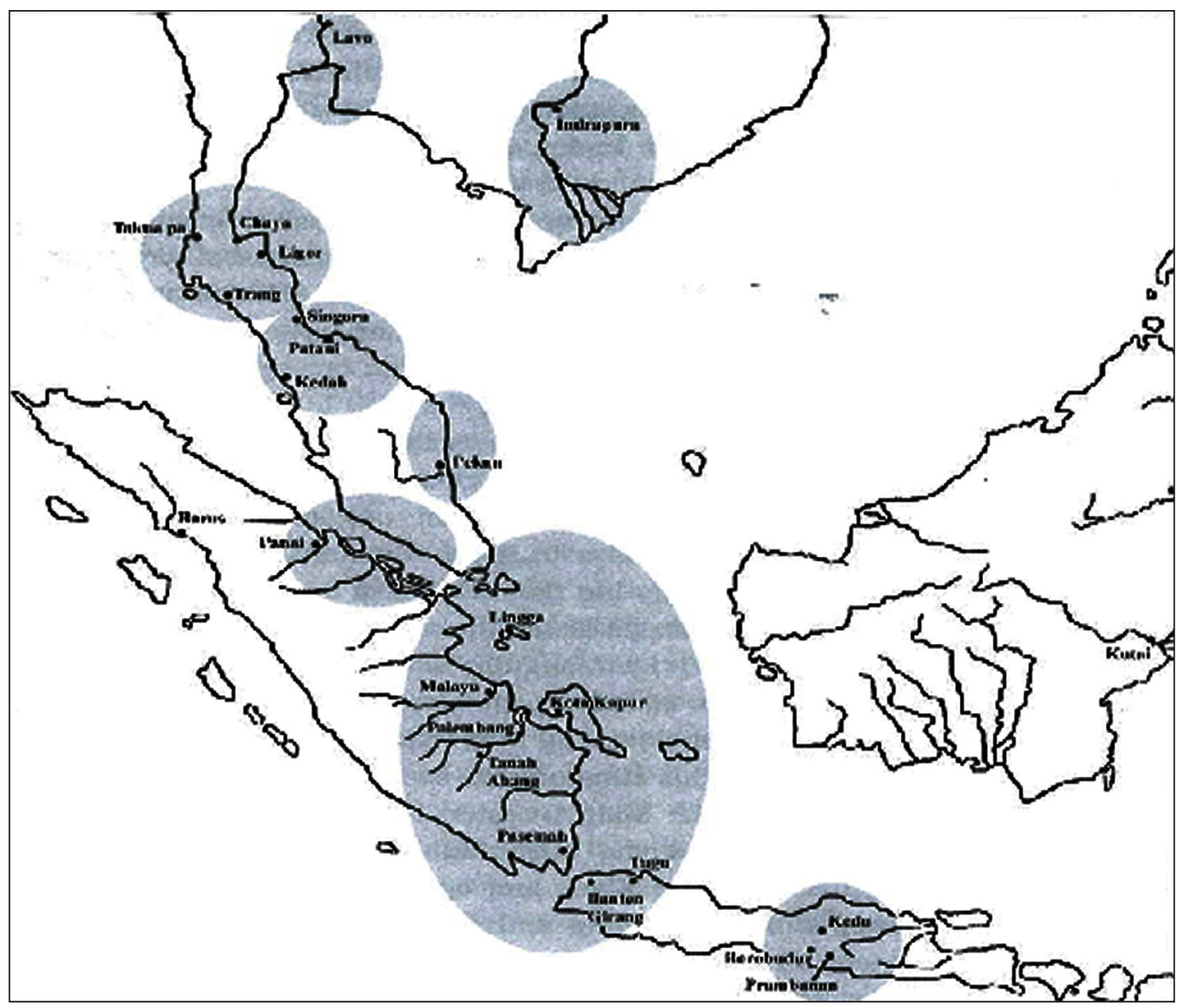

Map 2. Srivijaya influence, maximum expansion (Munoz 2006: 118).

By this time, Srivijaya had become the dominant power. It gained influence because it was an entrepôt port of Chinese, Indian, and Arabian trade. It was equally important for its local population who brought goods and forest products from its own hinterlands in Sumatra and from indigenous traders from the Archipelago. They were much in contact with each other and with the Kings of Srivijaya as their overlords in this widespread Mandala. Wolters 
(1982), Andaya (2008), and Munoz (2006) spoke of the Mandalas of this state, and how they were kept under its power. There were allegiances, warnings on inscriptions, marriages, but most of them could only dream of the richness of Palembang, if they were loyal.

While traders congregated, Hindu and Buddhist monks would gather to study sacred texts. For them, these Southeast Asian stops on their way further east were important, for there were famous gurus and monks here too. There were monasteries, and reports say that Malay was used for instruction.

The administrators of Srivijaya were in contact with its tributaries, the Mandala, where trade and administration were carried out. These places had different levels of density; centers like Palembang and Malayu were more populous, while Barus and Pekan were much less so. To the periphery would be the local farmers, craftsmen, builders, and closer to the sea fishermen and sailors - who fed the city and assisted it in the provision of food and in transportation.

It is my belief that pantuns form grew and spread from Srivijaya, and most probably from around the city of Palembang or Malayu. When Palembang became more dominant, pantuns of the two cities would be known to each other's population, and while they used the same language, they were adversaries politically. Munoz (2006: 117) is of the opinion that the Malay language grew from among the mangrove villages in the estuary of the Musi, though other theories point to Borneo as the homeland of the Malays and therefore also the homeland of the Malay language (Collins 2000). From there, Malay was brought to South Sumatra. Whatever its real birth place, I think its next stage, that is, the second phase of development was given a great push by the power and influence of Srivijaya, which gave it a great impetus, glamour, and a corpus of vocabulary for the various sectors of living - from agriculture to the boat-building, to trade, religion and international relations. While Palembang had all these technology and skills, its language, old Malay, was able to act as the vehicle of contemporary life.

Palembang was not only the entrepôt for trade in gold and forest products, but was also a great market for ideas and languages, and new skills and goods. This dynamic state of things influenced the language of the city and the Srivijayan Mandala. All the states under its power were not only in close contact with the center but also offered it their cultural products, the fine fabrics from the islands, tin and gold and not to forget their literary offerings. The kingdom's traders and officials would have undertaken more organized and structured journeys. Most often, they travelled with the northeast and southwest monsoons, and when the winds were not so favourable they would linger for months in the ports or would wander into the hinterlands in search of new products or designs. This would also have been the time to share experiences, make friends, and exchange cultural offerings.

Traders and sailors from distant Kutai, Kedah, and Singgora would no doubt have been interested in the stories, songs, and poems from Palembang, the great city and their powerful overlord. Naturally, of special interest would 
have been what happened in the center of the Empire and in other cities. Palembang was indeed the cultural center of the Archipelago and at the same time, its mandalas were also the consumers of its offerings.

Thus the pantuns of Palembang and its territories and hinterlands, and other poems taken there by sailors and traders from other islands would have been heard and liked and favourite ones memorized. A rare few would have been copied by those able to write. When it was time to depart, they would have taken them home, in their memory and on pieces of lontar palm leaves, cloth, or even on bones to be shared and enjoyed. If they were Malay speakers the transmission of the Palembang or Malayu poems would have been more direct, if they were not, then they would perhaps have been translated or imitated as to form, structure, and melody. For pantuns, which have simple and flexible rules, imitation in other languages would have been as easy as rendering them into local languages. They would attract many because they deal with universal and thus relevant themes - love, parting, advice on behaviour, proper values, and goals in life, but not least because they were dynamic. By the tenth century, many Malay-language speakers would have become as passionate about pantuns as the Malays of Palembang themselves.

As one surveys the pantuns from different regions one finds beautiful verses that use dialect words, and special references to environments and local circumstances. In Southern Sumatra, for example, we read of the following verse (Dharmawan Nur Silahuddin 1990).

\section{Hati-hati makan timun,}

Timun itu banyak bijinya;

Hati-hati kalau melamun,

Melamun itu banyak artinya.
Be careful when eating cucumber, The cucumber grows many seedlings, Be careful when you dream in your slumber Dreaming has many meanings.

In the Enim district of the Musi, Sucianti (1994: 91) finds a poem that advises: should you want to become a person who benefits the community, do not forget to go first through the difficulties of life.

Kalu adiang pegi ke umou, Jengen lupou mendi di ulu; Kalau adik nak jadi orang berguna, Jengen lupo saro dahulu.
Should you go to the clearing, my dear, Do not forget to dip in the cold stream; If you wish to be a person of worth, my dear, You must first suffer for your self-esteem.

In present day Jambi (Umaruddin 1995) we find the following lines.

Cuba berpucuk kau bayam, Kami hendak memupul selaronyo; Cubo berkukuk kau ayam, Kami hendak mengenga suaronyo.
You spinach, rise and grow, We wish to gather your leaves of choice; You cockerel, raise the morning and crow, We want to hear your voice

Crow you cockerel, the poet says, which may refer to a loud-mouth, who, for once, forgot to speak up. 
In fact, as the terms used for pantuns among the Batak tribes reflect earlier Malay names like upama, umpasa (in Malay umpama, proverb, simile), it is likely that Malay influence was still felt in the this early development, when they were still two-line proverbs or when they were just changing into a new four-line ones, still known as perumpamaan. Those in the Malay-speaking areas would have repeated, reused, and recreated pantuns or composed new ones to reflect their own particular circumstances and themes and thus adding to the general pantun corpus in their own dialects. When they were highly relevant and artistic, sailors and other travelers would also have brought them from Muara Takus to Palembang and to other groups and tribes. In this way, Minangkabau verses would come down on boats into the valley of the Batang Hari, and into Malayu and Palembang and the surrounding areas. Therefore, pantun development may be as complex as the relationships, the inter-influences, sharing of images, and intertextual elements grown from older Palembang stems. By the tenth century, composers and communities would have become quite skilled in composing intricate, memorable and finely wrought pantuns. There would have been unconscious and indirect competition between different communities to produce the best and the most original verses, and to put them to music.

\section{CARRIED UNDER THE SAILS}

The history of the Malay Archipelago is predominantly a maritime one (Andaya: 2008). Important states like Majapahit, Srivijaya/Melaka, Johor, and Aceh all depended on the sea, its trade and its resources. Out of any one of these centers ships could sail the entire Archipelago, and could call at the ports of Makassar, Ambon, Pattani, Aceh, Jayakatra, Siak, and Padang.

As has been suggested earlier, several Orang Laut or Sea Nomads communities not only have a long relationship with the sea and riverine states but also played significant roles and exhibited expertise no other people could surpass. These maritime communities ${ }^{5}$ assisted in the commercial and diplomatic relations between the states, but may also have been involved in building other important, but perhaps less visible, links. They were so extremely important that the most famous culture hero of the Archipelago, Hang Tuah, most probably originated from a Sea Nomad tribe in Riau, either from the Kanaq or the Sinkep community.

To the east of Sabah, the Bajaus or Sama di Laut, a Sulu community, is considered as originating from the Southern Philippines. They are now, and perhaps were also then, not large in number, but surprisingly widely dispersed all over the Archipelago and they played important roles in the kingdoms in Sabah, Brunei, and Flores. They were closely linked as they followed $l e^{\prime} \mathrm{od}$ or community-loyalty principle, and not surprisingly were

5 Like the Seletar people (in Johor, Singapore and Riau); Kanaq (in Northern Riau), Bajau (from Southern Mindanao to Eastern Kalimantan right through to Flores and the other islands to the east), the Urak Lawik (in the islands along the coasts and islands near the borders of Malaysia/Thailand/Myanmar). 
able to trace their bloodlines to many villages and ports in East Malaysia and throughout Indonesia.

Families sailing the Sulu Sea carried Bajau and Malay pantuns, for example, in their leppa boats going from one village or temporary dwelling in Tawi-tawi, to their relatives in Sibangkut Island or Semporna, and then on to Tawau, Lahad Datu, Kudat, Brunei, Teluk Bone, Manado, Banggai, and other coastal hamlets in Sulawesi and Timor. From the eastern coasts of Kalimantan, they could easily sail to Maumere, Flores, from where they crossed the northern waters to Labuhanbajo (Port of the Bajaus) at the western tip of the island. Thus, the routes of their journeys were long and intricate and on these journeys they carried, besides food and implements, selected proverbs, verses of songs and pantuns, all already embedded in their memory, rituals, and feasts. New poems were probably composed as well, reflecting novel experiences and new locations where the corals were more beautiful and the sago more abundant.

These journeys sustained the pantuns among the Bajaus of the Southern Philippines and on the eastern coast of Sabah, in Maumere and Labuhanbajo in Flores. A Bajau pantun or kalang from Kota Belud, known as isun-isun (quoted by Inon Shahruddin (2002:130)) goes like this

Kekanda si isun-isun

Isun-isun di dalam gelas

Ku kasi pantun ku minta pantun

Pantunku tidak terbalas.

Kekanda si isun-isun

Isun-isun di dalam dulang

Ku kasi pantun, ku minta pantun

Pantun satu dibawa pulang.
My beloved, the isun-sun dancer, The isun-isun is in a glass coloured; I offer a pantun, and request an answer, But my pantun you've not replied.

My beloved, the isun-sun dancer, The isun-isun is in a tray; I offer a pantun, and request an answer, A pantun for me to take away.

According to Inon Shaharuddin, isun-isun have a tune that may also be used in narration or in singing other poems. The tune was passed down over the generations, but is now recorded for more efficient recall.

References about the Bajau are far and few in between. For lack of other sources, I used blogs, which to me are comparable to oral information from informants from villages and islands. "Blog abnaddin" gives us a rare glimpse of this tradition. In social or ritual gatherings, a female pantun speaker is paired with a male one. A violist accompanies them. The occasions are mostly births, marriages, and the fulfillment of nazars or wows. Their themes are quite free, but mostly focus on deeply-felt emotions and the relationship between young people in love, that is, flirting, courting, skulking, pujuk, asking for a girl's hand, marriage, and other similar situations. In the northeast of the Malay Peninsula, we find the Urak Lawik who also use Malay as one of their languages. They inhabit the Lepe and Adang island areas and live along the coasts of Myanmar's southeastern border with Thailand. Some of them have settled to the north of Phuket. Like the Bajau they too take their pantuns with them whenever they move, and share them with other communities, and most 
of them are repeated or composed during special festivals. We have only a few verses from Lepe. I quote a humorous one. The woman says she suffers because she wants to follow the man she likes, but unfortunately, he is already somebody else's husband.

Sakit kaki terpijak siput,

Siput datang dari seberang;

Sakit hati rasa nak ikut,

Tapi sayang lakinya orang.
My feet are sore, cut by the shells, These shells from over yonder; My heart is sore, it wants to follow you, But you are someone else's husband!

We have another bit of information about the Orang Laut's relationship with pantuns through a description made by Abdullah bin Abdul Kadir Munshi (1838). On his way to Kelantan, he collected several verses, probably from the crew of the boat on which he sailed. He copied about 50 of them, which were intermixed with the Kelantanese ones. However, if my guess is correct, the ones that refer to the sea and to life on the boats probably belong to the Orang Laut. Here is a verse, very sophisticated and mystical, and as good as any composed over the centuries: Abdullah bin Abdul Kadir Munshi 1838.
Mentimun bulat, panjang ta' lebar, Ketiga dengan biji-biji-nya;
The cucumbers are round, long but not wide, Lautan embun, karang terbabar, Their seeds they make three;
Alam bergerak dengan sendiri-nya. The world moves on its own and free.

W.W. Skeat (1900: 204) collected another pantun from an Orang Laut in Selangor. It was used to dispel the sea's evil spirits. It is a full-blown verse, though the last line is adapted to be used as a mantra.

Pisau raut pisau rencung

Terselit di banir pulai

Hantu laut hantu kampung

Minta undurkan hantu laut hantu rimba.
A carving knife and curved blades, Hidden among the great pulai roots; Spirits of the sea, and guardians of the glades, Pray, from our village to exclude.

\section{SUMATRA}

The different Malay kingdoms in the Archipelago also helped the growth of Malay dialects. These dialects similarly allowed for the creation of thousands of new or imitated pantuns. ${ }^{6}$ The last count revealed that 40 Malay dialects are used to sing or speak pantuns, each in its own pronunciation and using local imagination and creativity.

The following is an example found among the Proto-Malays of Riau. It advises not to eat the poisonous fruits or to climb trees with thorny trunks. In short, do not seek danger, and always act using common sense.

6 At present we can listen and read pantuns in the Malay dialects of Ogan, Komering, Kampar, Bangkahulu, Minangkabau, Kerinchi, Rawa, Riau, Bengkalis, Siak, Bangka, Langkat, Deli, Petalangan, Sakai, Kampar, and many others. 
Apo bedobuk seboang pekan,

Buli-buli dik nan kono joat;

Buah nan mabuk jangan dimakan,

Batang bedui dik jangan dipanjat.
What falls in the market beyond,

It's a bottle, being encased;

Consume not the fruits dark with poison, climb not trunks dangerously spiked.

Further north, in the Langkat area (Masindan et al. 1987: 15), we find this poem

Kayu ara dimakan api, Derai kata ungkapan hati;

Masa berobah dikisari,

Adat tetap pengasah budi.
The fig tree is consumed by fire,

Words fall, like leaves of the heart;

Times may change, and we expire,

But the adats are an easel of civilization's art.

The lines speak of how times change, and how man must change with them. However, adat (customary beliefs) are forever the instrument for the refinement of a person. Over the mountains, in the Minangkabau homeland, pantuns are expressive and passionate. From a book of old proverbs by Aman B. Datuk Madjoindo (1999: 6), I chose the following verse.

Ka hilie jalan ka Padang,

Ka mudiak jalan ka Ulakan;

Kok musuah indak dihadang,

Kok basuo pantang dielakkan.
Up the mountains to high Ulakan,

To Padang, downhill is the road,

Enemies, we do not seek to confront,

But when met we do not avoid.

This verse speaks of a strategic relationship with other people or communities. The enemy is not stopped on the road to be engaged in a fight, but when confronted one must be ready to duel.

Among the Kerinchi people, I found fine poets and keepers of the memory of their past literary gems (Salleh and Bahaman 1999: 96). One of them is illustrated by Meiniarti (Salleh and Bahaman 1999: 103) the following quatrain.

Sarangung pasa Saleman, Tampak nan dari Tanjung Tanah; Teguh-teguh pegang padomua, Jangua bedik karang di tengah.
Sarangung the market of Seleman,

You can see it, there it gleams;

Hold fast to your course, make your stand,

Let not your boat sink mid-stream.

It speaks of the need to follow instructions, if one is to avoid drowning in the middle of the sea. It thus refers to proper learning and discipline.

Besides traders and merchants, immigrants from numerous countries of origin flocked to the commercial, administrative, and cultural hubs on the islands. They brought their own cultures and shared them with the local inhabitants, both for the sake of communication and to integrate. Over the centuries, they started to appreciate and to adopt local literary forms for their own expression. It is interesting to note that for many descendants of these emigrants, pantuns seem to have been the most popular choice. We thus see pantuns composed by Peranakan Chinese in Melaka, Penang, 
Singapore, Betawi, Semarang, and Surabaya, and in Melaka also by the Ceti, the descendents of Indians who married Malay women.

Although Sumatra has many varieties of pantuns and used for many special functions, as yet they are inadequately documented as to their dynamic quality and distribution. However, as I have suggested earlier they also spread through language, from the Malay-speaking areas to the non-Malay speaking ones. This I would think is logical path.

The next factor is the movement or migration of pantuns from one community to newly established communities, or to pre-existing ones. For example in the Komering area of south Sumatra, pantuns may have been taken to the Ogan, while from Jambi they were taken to the hills of the Kerinchi people, who now have a wonderful corpus of their own. From Bangkahulu, in the east, they may have been taken to other ports like Barus, Lampung, and Aceh.

From Palembang, sailors followed the winds or the currents to Kedah, Perak, and Pahang, thus not only allowing verses to be shared but also to provide models for new pantuns to be created. There was in fact a very intricate and complicated internal network between the different communities of the Malay peoples, while there was also a larger network that involved non-Malay groups on the islands and in the Peninsula.

Pantuns dispersed from the core of the Malay language areas to their closest non-Malay speaking neighbours: the Batak sub-groups, especially the inhabitants of the lowlands - the Mandailing, the Dairi, and the Pakpak. As alluded to before, pantuns came to be known to the Batak when two-line proverb-pantuns were popular among the Malays. Their terms for the pantun are mpama and umpasa. We can perhaps deduce from this form of naming that either the form came to be known to the Batak groups when it was in its earliest stages, or the word was created to identify the four-line form describing its function as a simile. As an example we hear in Simalungun this verse (Tarigan and Tondang 1980: 14).

\section{Mardemban marnapuran, Mangisop martim bahou; Marlengah ma untungkan, Marimbanghon parlahou.}

\author{
Enjoy your betel quid, fresh and green, \\ Smoke your tobacco of many flavours; \\ Our fate is all confusingly different, \\ Everything is contingent on our behaviour.
}

The original lines are seven syllables long, with a clear division between the first two lines and the meaning proper in the next two. The rhyme is likewise close to that of a pantun, that is, a b a b. Ahmad Samin Siregar (Salleh and Bahaman 1999: 297) collected several Mandailing pantuns, including the following, where the speaker apologizes for words that have crossed the threshold of acceptability and polite behaviour. 
Pusuk na santanjur,

Naigotap dohot piso balati;

Pala adong obar na talanjur,

Mangido mohop ma sannari.
A bundle of tobacco wrapper-leaves

Cut them with a knife, clean and nice;

Should anything be delayed or late,

I now seek your forgiveness.

Perhaps around this time, the Acehnese of the northern part of Sumatra and the Gayo would have come into contact with this form, either from the sea or from the Malay speaking region to the south. At present, this form is quite alive in northernmost tip of Sumatra, for example, this poem for young lovers.

Ranub seulaseh lingka pupalang, pineung muda krang dalam seunalob; Gata kugaseh kon wayang-wayang, na nyeum be' leukang dalam seulimbot.
The betel grows by the wall of the well, The young areca nut dries in the heat; I never feign my love, for your approval, I'm stuck to you like bodies under the sheets.

The Acehnese also use pantuns in courting and in ceremonies to ask for the hand of a young lady in marriage. The Gayo in Aceh's southern highlands and therefore comparatively close to the Malays, would be among the first to receive the form more directly, and/or perhaps later, indirectly through the Acehnese, from the coastal areas or the lowlands. From the Malays of the west coast, possibly the Minangkabau, who had influence over the islands to the west of Sumatra, pantuns spread to Nias and Serawai, where we also find examples in the islands' own languages.

To the south, pantuns spread to Lampung, where they are known as segata or adi-adi, and are mostly used for entertainment. The rhyme scheme can be $\mathrm{ab}-\mathrm{ab}$ or aa-aa and there is a division between the first and the second two lines.

\section{THE PENINSULA}

\section{The North}

In contemporary Malaysia, the north has among the largest number of renowned practitioners. However, this says nothing of the dates of the emergence of pantuns here. Whatever the case, there are some examples from Tunggu Padi Jemoq (Ramli M.I. 2006: 178), which show evidence of earlier, simpler and more playful structures. For example in this children's poem.
Mari-mari adik,
Come ye brothers
Mari-mari abang;
Come ye sisters,
Kaki saya capik,
My feet are in pain,
Sepak batang alang.
After kicking wooden rafters.

A little further to the north, from what was once the famed kingdom of Pattani, we may hear lullabies like this (Nureeyan Saleh 1999: 31). 
Endoi-endoi tiak,

Tiak makan padi, Adik jangan teriak, Emak cari padi.
Dandle the finches high to the sky,

Finches feeding on the padi;

Weep not my little sister, try to be shy,

Mother is busy harvesting rice-paddy.

Interestingly, even this lullaby, in which one tends to look for local colour, references, and originality, has some intertextual qualities with those from Kedah and northern Malaysia. Again these traces, though without the specific route mentioned, provide evidence of the pantuns' journey. It seems that though the Malay-speaking countries were spread far and wide, many basic poems in lullabies, games, and love-plays are shared throughout the region. In these cases, dialects are a matter of mere pronunciation, but the contents of the language belongs to all. Pantuns obviously travelled with the journey of the language.

Kedah, Perlis, Pulau Pinang, and northern Perak are considered to form a distinctive cultural area. From the northern lowlands to the more mountainous Perak we have a substantial corpus of pantuns. Perlis and Kedah still exhibit a living traditional storytelling tradition, verse capping and informal competitions; though these are now fading as the last oral poets age and young people choose other forms of entertainment. Like the poems of other areas, they tend to be close to nature, to their environment, and to their individual or shared social experiences.

The following poem from Perlis (the state was part of Kedah much earlier) refers to the Chuping Hill and the Beringin Cave, where guano was collected as fertilizer. These images or references also prepare for the meaning proper, that is, do not fall for the fair one, for many have been left empty handed.

Bukit Cuping Gua Beringin,

Tempat orang ambil baja;

Putih kuning jangan diingin [original], Banyak orang balik saja.
The Beringin Cave in Cuping Hill, Where guano is gathered, Crave not for the fair one, with the earring, Many have returned empty-handed.

From Perak, another pantun refers to Lambor, a village near Kampung Gajah. It describes how the earth of Lambor is swampy but fertile. If you choose to settle there, you should come with a partner.

\author{
Tanah Lambor tanahnya lembah, \\ Tanam keduduk bercabang dua; \\ Memang tanah Lambor ini bertuah, \\ Siapa nak duduk mesti berdua.
}

Lambor is a valley soft and wet, Graft the rhododendron with two branches; It's true Lambor is indeed fortunate, Whoever comes must bring a partner

The capitals of the kingdoms to the north, especially Kuala Muda and Kuala Kedah were also hubs and points of gathering and dispersion for pantuns and their magic. Later, in the fifteenth century when Melaka had become a great port and a influential state, it would adopt similar roles on behalf of this verse form. 
Selangor and Negeri Sembilan

Dari Kelang ke Kuala Langat, Singgah bermalam di sawah padi; Hati terkenang mulut teringat, Macam jantung lekat di hati.
From Kelang to Kuala Langat, you hear the calls, Stay and spend the night in a rice paddy, yonder, The heart remembers and the mouth recalls, Like the heart is attached to the liver.

This Selangor poem refers to the two big towns Kelang and Kuala Langat (Ahmad et al. 2002: 249), while the last two lines conclude, "The heart remembers and the mouth recalls/Like one that is attached to the liver". Forever connected to each other, the mouth always remembers on behalf of the liver (the seat of Malay emotions).

From Negeri Sembilan, we choose a rare six-line pantun.

\author{
Rumah gedang bers(t)ingkap tidak, \\ Di mana angin nan lalu, \\ Entah di ruang-ruang lantai; \\ Hati memang bersikap tidak, \\ Di mana orang kok tahu, \\ Entah di situ nan merasai.
}

\begin{abstract}
A great house without windows, Where shall the wind blow through, Perhaps among the floor boards; The heart is ready to reject, How is it that so many have known, Perhaps it's there where one feels.
\end{abstract}

The poem wonders that though the liver (heart) does not speak its intention, how is it that people come to know of it. He answers - perhaps the liver is the location of all emotions, and therefore anybody can peek at it. Terms like nan, kok and merasai are recognizably Negeri Sembilan and Minangkabau. The experimentation with the 6-line (or more) form is also unique to the state.

\section{Melaka, Pahang, and Johor}

When Melaka became a great entrepôt port in the fifteenth century, pantuns became part of its literary culture. They were perhaps at first oral, but then seeped into written works, such as the Sulalat al-salatin or Sejarah Melayu. Some of these poems originated from Palembang, which may well have taken them from other parts of Sumatra, because it was a great international port. With Malay known in the eastern islands of Indonesia, quite early pantuns too were taken in boats to these faraway places. Melaka attracted traders from all over the islands and beyond. When they sailed home, they took with them pieces of Melaka, in their boats or in their memory. These were usually verses or songs, proverbs or lines taken from adat laws that touched their emotions through their brilliance of metaphors or repartees, in their allusions or even their introductory lines. These were taken home as presents, as surprises, just as one would memorize a song once heard in a makyong dance drama or the dondang sayang in the 1930's, or nowadays from new songs from Jakarta or Kuala Lumpur. These were indeed verses or lines from the hubs of culture, and were examples of their brilliance.

Besides Kedah and Melaka, Pahang and Johor would have been the other 
main pantun hub in the country. As the pantuns took root they spread fast, and were carried into the hinterland on riverboats or by travelers who traversed on foot into villages in the upper reaches. As rivers no doubt provided the fastest means of transport, verses may not only have been found in ports and estuaries, but they were also composed deep in the countryside. Farmers, and honey collectors, folk healers and elders, lovers and speech makers, all composed lines for their own needs and their own situations. Some lines were clearly borrowed from or shared with other states and villages, but many were composed at dondang sayang, berbalas pantun or at social gatherings. In Melaka many were the verses that were memorable, with unique lines and clever maksud.

I copy two verses of the dondang sayang genre, in which a man teases a woman and she replies, often impromptu, according to the beat of a song, A man sings the first, boasting that he has no fear of the tiger, for no one dies before his appointed time. This he directs to the young lady.
Angkut-angkut membuat sarang, Jatuh berderai di atas peti;
Mason bees busy building their nest, It falls asunder over the chest and twine; Apa ditakut harimau yang garang, I have no fear of tigers, but not the rest, Sebelum ajal berpantang mati.
For whoever dies before his time?

The young lady answers: if you are so brave can you catch a cobra and make it your pet?
Tinggi, tinggi rumah Cik Long, Di bawahnya dibuat kedai kain; Alangkah bisa ular tedung, Bolehkah di tangkap buat main?
Cik Long's house is high on stakes, A shop selling cloth right under it; How poisonous the cobra, a killer snake, Can you catch it for a pet?

It is here in Melaka too that Chinese and Indian Peranakans adopted the form and it bloomed with their talents and their special use of the verses. For Johor, (along with Singapore, which culturally is still part of it) we quote the following quatrain.
Di Tanjung Katong, airnya biru,
Di situ tempatnya dara jelita;
The waters of Tanjong Katong are clear and beaming
Duduk sekampung, lagikan rindu, Kononlah pula nun jauh di mata.
That's the place of pretty maidens;
Even within a village I am so full of longing, How shall it be when we're far apart, my friend?

Though we live in the same village, stresses the poem, we still pine for one another. How more painful will it be, the poets ask rhetorically, when they are far apart? 


\section{Kelantan and Terengganu}

Kelantan, the dynamic state on the east coast of the Peninsula was (as it still is) a throbbing hub of traditional culture. The different forms of performances like the shadow play, makyong and dikir barat took root here and were encouraged by enthusiastic and passionate audiences. The performances too were included pantuns in their narration and dialogue. An early one goes like this.

Itik Tok Teh, itik Tok Tanjong, Ambil benang buat koyak; Adik putih ngelek buyung, Kacip pinang abang sepiak.
The swan of Grandma Teh, and of Grandma Tanjong, Fetch the thread for a tear;

Fair one, who carries a water jug alone, Please prepare me a quid of betel, my dear.

In the following poem (most possibly from Terengganu) the Dungun River is the place to place a fish cage, but the poet complains, for he does not catch any fish. The poet then asks his beloved, why she is sad, and wonders whether it is because of something he did (Mohd. Thani Ahmad et al. 2002: 544).

Tahan bubu di Sungai Dungun,

Seekor ikan haram tak kena;

Mengapa adik duduk termenung,

Di manakah tempat abang tak kena?

We should not overlook the literary contribution of the Orang Asli, the First Malays, who enjoy and often compose and sing pantuns at a variety of social functions. We see examples of quatrains composed by the different communities, including the Mahmeri, Semelai, and Urak Lawik. Kak Hakek (Salleh and Bahaman 1999: 189) sang the following lines from Bera Lake in Pahang.

Tahan lukah orang mandi, Ambil kain tangguk basah;

Bersumpah takut mati,

Betaroh takut kalah.
Set a fish trap near the bath pool, Take a sarong for a netting; I won't take a vow for fear of death, I won't take a bet for fear of losing.

\section{KALIMANTAN/BORNEO}

\section{Sarawak and Sabah}

At least 40 ethnic groups inhabit Sabah and Sarawak in the northern part of Borneo. Besides Malay, they use the languages of the Bajaus, Murut, Kadazandusun, Iban, Melanaus, and Bidayuhs. Besides the Malay-speaking Sabahans and Sarawakians, the descendants of the Bruneians, would be closest to pantuns. They use them in lullabies, children's games, courtship, marriage ceremonies and also in all kinds of other forms of entertainment. The following example illustrates one of their more direct verses (Ahmad et al. 2002: 666). 
Banting-banting tumbuhlah damit,

Disukat bahagian panjang;

Pengantin lagi damit,

Ibu bapa akan menentang.

The poem refers to the relationship and the proposed marriage between two lovers or the proposal to ask for a young girl's hand. The bride is still young, and therefore most probably her parents will not agree.

As has been shown earlier, not only the descendants of the Brunei Malays in Sabah and Sarawak use this poetic forms. The Bajaus are equally passionate connoisseurs and so are the Bidayuh and the Kadazandusun.

Sarawak river pantuns are widely known and use successful lyrics in very popular asli, or traditional, tunes. There are several versions. The following version (Ahmad et al. 2002: 640) is the more popular one.

Sayang Sarawak muaranya sempit,

Tuan datang dengan rombongan;

Hendak dibawa perahu sempit,

Tinggalah emak tinggallah junjungan.

With the river as backdrop and a boat about to sail, the poem describes how a group of visitors has come to visit the poet. However, as his boat is narrow, he cannot carry anyone else, not even his mother or his beloved, and can only wish them all goodbye.

Interestingly, the Iban also use the term 'pantun` for one of their poetic forms, but it is quite different as it is, in Chemaline Anak Osup (2006) words "a rapid speech-like, rhythmically free singing on one tone".

Brunei shares a literary tradition with Sabah and Sarawak. Once a powerful Sultanate, it exerted influence over both these states. Unsurprisingly, they too are proud owners of their own pantuns, locally composed and in the local dialects. One of them goes like this.

Raja bertitah di pataratna, Memakai baju sampang biludu; Pantun sapatah banyak mahana, Jika dijumlah bukan seribu.
The raja commands from his high throne,

Dressed is he in a velvet sampeng,

A word is not laden with a single meaning alone,

If enumerated, more than a thousand.

It refers to a single word or pantun, but how numerous indeed are its meanings, if you enumerate them they would be more than thousand.

Pantuns in the different Malay-speaking areas of Borneo/Kalimantan such as Brunei, Labuan, Sarawak, Sambas, Pontianak, Ketapang, Banjar, and Kutai, may have taken routes of a similar nature as we saw in their spread in Sumatra. Chairil Effendi (2009: 4-5) in his study of "Oral tradition and identity of West Kalimantan society" describes West Kalimantan society as living in a state of primary orality. This fundamental reality enhanced the spread of pantuns not only among Malay communities but also among the Dayak (Asfar 2003). In general, West Kalimatan has an intimate relation with pantuns. The 
Malay groups use them quite intensively, and they are also present among many Dayak groups, though to a lesser degree of usage.

In the Malay-speaking Sambas community in West Kalimantan, villagers are very proud if they are able to recite, and prouder still, if they are able to compose impromptu pantuns. Chairil Effendi collected the following poem from this community (Salleh and Bahaman 1999: 163).

\section{Pisang kappo dibuat kolak,}

Pisang ammas dalam ke'ranjang;

Datang rezeki usah ditolak,

Mun dah maut usah ditatang.
Cook the kappo banana for desert,

The golden ones are in the basket;

When good fortune comes reject it not,

When death comes fight it not.

He found the following poem from Sintang to greet visitors and to wish them a sincere welcome.

\section{Ada batang tetakan, Udah ditetak di pulak gedok; Selamat datang kamik ucapkan, Kamik ehlas silakan duduk.}

\author{
There's a branch cut from the trunk, \\ Into a drum it is fashioned; \\ We welcome you all, dear friends \\ Please kindly be seated.
}

In the southern Kalimantan region, the Malay-speaking Banjarese are likewise quite famous for their pantuns, which they use during rituals, at social occasions, and during ceremonies. Like other Malay groups, they too use the form during weddings. The following verse asks whether the people of the house have returned, for the speaker wishes to visit them, most probably to inquire into the possibility of asking for the hand of the maiden residing there (Sunarti et al. 1978: 132).

\section{Apa burung betetkah, Bari-bari hinggap dibatang; \\ Apa tetakah sudah di rumah, Ini hari kami bedatang.}

Banjarese pantuns are often oral but they have also been copied and published. They are used in South Kalimantan and in neighbouring provinces and countries, including Malaysia and Brunei, to which they migrated. Tajuddin Noor Ganie (2006) claims that pantuns are often anonymous and closer to entertainment, and resemble Banjarese folklore. Interestingly the Banjarese form is also considered as a development of Banjarese peribahasa (sayings). In addition, the term used for this form is pantun, as in Malay. Some of them still survive in ceremonies as described above. Otherwise, religious teachers use them to enhance their teaching techniques. It is said that during the golden age of Banjarese rule (1526-1860), pantuns played a significant role in entertainment, and as instruments of rhetoric, which therefore presupposes that chiefs should be well-versed in them to be able to express themselves and their communities' wisdom and perhaps also to compose lines spontaneously. 
In this community, there were also other gifted persons who were professional tukang olah or tukang baca pantun. In Banjar, competitions were held between poets in a ceremony called Baturai Pantun (Pamantunan). In fact, it is believed that there is a "Datu Pantun", a pantun god who, in the Banjarese pantheon, inhabits Alam Banjuran Purwa Sari where the gods of the arts reside. He is considered the first pantun speaker and its originator.

To the east of the island is the ancient Sultanate and now Province of Kutai. Interestingly, there is an ethnic group by the name of Pantun there, and a village by the name of Sri Pantun in the sub-district of Kongbeng, East Kutai. The relationship in meaning or the significance between pantuns and this group is yet to be established.

We have some examples of pantuns from the province itself (Salleh and Bahaman 1999: 123), which were collected by Endang Dwi Sulistiowati. The following verse describes the fate of a stranger, alone and suffering in the long night.

Purnama indah terang cemerlang, Sangatlah terang di malam hari; Sudahlah nasib di negeri orang, Merista badan sepanjang malam.
Such a beauty is the night of the full moon, The world is now filled with light; It is my lot as a man marooned, Nursing my suffering in the long night.

\section{JAVA}

If we cross over to Java, we find that pantuns are used in many parts of the island, from the east right through to the west. The following example, in Javanese, comes from Surabaya (Kunardi Hardjopradjoprawiro 1985: 316 ).

Margayasa marga rukun, Klambi ireng karo spatu; Barek kanca ayuk sing rukun, Aja seneng tukar lan padu.
Margayasa is a peaceful clan,

Wear a dark shirt with your shoes; Live in harmony with your friends, Avoid quarrels that cause woes.

As one goes to the west of the island, one comes across sisindiran in the West Javanese Sunda region. They are indeed closer to Malay than to Sundanese pantuns, which are different altogether because they are in fact long narrative tales. The following sisindiran is posted in http://en.wikipedia.org/wiki/ Sisindiran.

Sok hayang nyaba ka Bandung, Hayang nyaho pabrik kina; Sok hayang nanya nu pundung, Hayang nyaho mimitina.
How I long to be in Bandung, the highlander. There to see the quinine factory; How often I want to question someone in anger, To find how it all came to be.

In Bali, the form is known as wewangsalan, and perhaps came from the Javanese, especially those who left the island to migrate. I Ketut Jirnaya (Salleh and Bahaman 1999: 312) collected the following one in Balinese. 
Kubu linggah misi upih,

Gentong bolong misi buangit;

Kudu gagah ngaku ririh,

Kantong kosong sai nglamit.
Areca fronds in a hut,

A broken bowl full of buangit;

Well dressed, and claiming to be smart,

his pockets empty, looking for a loan.

This poem stresses the gap between the seen and reality. A well-dressed and well-presented person claims to be clever but unfortunately has nothing in his pocket and often likes to borrow.

\section{MAKASSAR AND SULAWESI}

Makassar is the capital of Southern Sulawesi, a main trading port and a cultural melting pot not only for eastern Indonesians, but also for people further afield, like Melakans, Chinese, Guajarati and later, Europeans. Like in other ports, tangible and intangible cultural artifacts are unloaded into the city and its hinterland. Makassar itself was a favourite port for Melakans; before Melaka fell in 1511 they had established a "Kampung Melayu" to the south of the city. Others moved to other kingdoms to become scribes for sultans and kings. Makassar was, and still is, among the most important disseminators of pantuns in Eastern Indonesia. After 1511, traders and members of the Melaka nobility migrated to South Sulawesi and took up residence in Makassar and Sopeng, among other places. In what are also known as pantuns in Makassar, as is evidenced by the collection of Sahabudin Nappu and J.S. Sande (1991), they are in fact freer in syllable count, and in their rhyme scheme. The last two lines are often a continuation of the first two in meaning and logical sequence. Therefore, there is no division between the maksud and the pembayang. This becomes clear from the following verse.

$\begin{array}{ll}\text { Pakrisik bajik nijulu, } & \text { Difficulties should always be embraced, } \\ \text { Simpung bajik niruai; } & \text { Worries resist being threaded; } \\ \text { Namana pace, } & \text { Though full of pain one must be steadfast, } \\ \text { Pakrisik katte nakke tommamo. } & \text { It all depends on how one makes one's bed. }\end{array}$

To the north of Makassar is the land of the Torajas with their unique culture. The form that is closest to the pantun there is called the londe. However, like in Makassar, its form is quite free and there is no division between the first two lines and the next two. We took this verse from Sande (1990: 352).
Inda pia to sambaliq,
Whose daughter is it across the river,
Mendiog rundun allo;
Daily taking her bath;
Bokaq pessuruqna,
With coconut oil she combs her hair,
Sammen pendioranna.
The water is her mirror.

Gorontalo is directly north of Toraja. Here, pantuns are composed in the Gorontalo language and in Manado Malay. Used in speeches, political campaigns, and in wedding ceremonies they are still very popular. Famous 
poets and speakers are often well-known and feature in radio and television programs.

\section{THE MOLUCCAS}

Today Ambon is renowned for its playful and amorous verses, and for the lyrics of famous songs which are now sung by Muslims and Christians alike in everyday life, during rituals and in ceremonies. Proselytizing, teaching the young, marriage ceremonies, teasing and wooing, and singing found in pantuns a ready and flexible medium. An early-published example (Angitong 1899: 352) goes like this.

Katemoean ini soenggoehnja kadang, Haroes memandang dengan bersoeka; Seperti boenga terbit di padang, Manis dan loonbot baroe terboeka.
The cucumber is indeed large, You should look upon it with joy; You are like a flower, sweet and gentle, Just opening in the meadows, quite coy.

One wonders how pantuns reached the islands of Sumba and Bima. Did they come from the west, or from the port of Sulawesi? Whichever way, the form is found on both islands where they spread quickly to smaller islands, up to what is now called Timor Leste. One example from Tetun, a Timorese language (from Martin Yosef Seran, Kupang, 25 January 2011), goes like this.

Taka sela ba kuda, Lunturu bete luturu,

Bete keta lun turu, Mai kikar kba mai kirar.
While saddling the horse, Weeps the maiden, Cry not young maiden, and make your voice hoarse, I promise, I shall soon return.

In Central Timor we also find a performance called bonet, a type of berbalas pantun, or verse capping competition. The old form spread across the entire island. From the capital, Kupang, there is a poem written by Gustav W. Petrusz. ${ }^{7}$ He describes a maiden who came to Kupang only to find it ringed by coral banks. So he says to her, with an open heart, that the people or Kupang lack nothing.

Nona manis datang ke Kupang, Bilang Kupang banya batu karang;

Beta bilang hati yang lapang, Di orang Kupang sonde kurang.
To Kupang did come a sweet maiden, Considers the town full of corals; I replied that they world quite open For they lack nothing there.

\section{PANTUN IN THE MALAY DIASPORA}

The Sulalat al-salatin (Malay Annals), Tuhfat al-Nafis, and Salasilah Melayu dan Bugis are works that trace the movement of the different races to the Malay 
Peninsula and back. Colonial records also contain evidence of the Malay Diaspora in Southeast Asia, especially after the fall of Melaka in 1511.

When it was a great trading port, Melakans travelled, lived, and traded in many of the islands of the Archipelago. Therefore, when Melaka fell, they sought partners in trade and safe places to continue to earn their living and to sell their wares. The most significant safe place was Makassar, where some of them became traders, while others, who were conversant with the art of writing and diplomatic correspondence became secretaries to sultans and merchants. Before or after the fall of Melaka a copy of the Sulalat al-Salatin, and with it also pantuns were brought to Makassar, where Malay was used as language of trade and diplomacy. It is very likely that pantuns entered the poetic tradition of the Makassarese and over time, gave birth to the Bugis kalang. There is a corpus of pantuns in Makassar Malay, which are closer to the Malay form. Melakans also settled in Timor and Munandjar Widiyatmika (Umar and Pudentia 2010: 262-278) describes the arrival of Melakans and the establishment of the Kingdom of Wesei Wehali, in South Beru, Timor.

Another form of immigration among the Malays was the result of colonialism and its economic interests. It was the result of the colonial conquest of Melakaa by the Portuguese, the British in the Peninsula, and the Dutch in Indonesia. Some Malays were exiled for political reasons; others were brought in as slaves or workers or to work as soldiers or labourers in colonial factories and on estates, while others came on their own. Thus, we find descendants of Malays, Javanese, and Banjarese in Sri Lanka, Cocos Island, Christmas Island and South Africa, and in Britain, the Netherlands, and Suriname. Again, these emigrants brought their languages, cultural artifacts, and memories with them. Among these were pantuns that were brought to Sri Lanka, which according to the History of the Sri Lankan Malays (2006), (http:/ / www. mpi.nl/DOBES/projects/slm/project), are called pantuns and "which have evolved such that they are more akin to the Sinhala Baila and other forms of linguistic competition" (Saldin 2001: 27-28). At present, they are sung at religious ceremonies of birth, circumcision, and marriage.

Jelani Harun in "Manuskrip 'Panthong' Sri Lanka", 8 notes the following quatrain, which is an early example,

Kuntum Mayang bunga sulasi, Rotan itu ada di Lingga; Tuanku minta hamba kasi, Bukan diberi dengan arga.
The bud of the coconut and a basil flower, The rattan in Lingga lies; My lord, you request my love to shower, But it cannot be given with a price.

This is a religious verse that advises that only when one knows God one will gain real knowledge, ilmu.

Thus, the spread of the Malays took several forms. Some were sent as workers and soldiers (as in Sri Lanka, Cocos and Christmas Island). Others

$8 \quad$ Http://melayuonline.com/ind/article/read/214/manuskrip-panthong-dari-srilanka. 
were political exiles or "convicts". Cocos Island, now part of Australia, can be said to have both elements but they have a special slant to them. In 1827, John Clunies-Ross landed with a group of Malay sailors from what is now Malaysia and Indonesia. They stayed on to become labourers for Clunie-Ross's coconut groves, and became the ancestors of the present-day islanders. Bunce (1993) made a collection of Cocos pantuns. It contains, for example this quatrain, and some words, the reader may notice, have retained their classical garb (Bunce 1993: 25).

Lengkuas hidup lengkuas mati, Melati kudup di tengah padang; Bercerai mati puas di hati, Bercerai hidup mata memandang.
A fresh galangal, a dry one,

The jasmine closes its petals in the meadows; If in death we part, it is all well done, If in life, eyes remain as the eternal witness.

If death separates us, I can accept it, says the poet, but if we are parted in life, then our eyes will continue to see pain and suffering.

\section{FINAL REMARKS}

Throughout history, pantuns have travelled far and wide. They began philosophically when nature was seen as man's mirror and subsequently as his teacher. It was logical that any form of expression had to contain natural and human elements. Initially they were found in brief and succinct proverbs that compared man to nature. Sometimes a word was mentioned that alluded to other words, which echoed its desired meaning, and the audience, raised in the tradition of allusion would have caught its meaning. This is the earliest definition of the word pantun, and perhaps this is the correspondence the Malays share with the Batak.

From the homeland of the Malays, the network of trade and maritime linkages brought about a situation where cultural riches from many sources could be enjoyed and shared, allowing each to take the gift of the other. Initially it would be from one Malay dialect group to another. Pantuns have been taken along in boats, from one village or port to another, from one state to the next. Subsequently they spread quickly to non-Malay speaking communities, for pantuns have the rare magic and the exceptional qualities of both simplicity and sophistication and they are adaptable to many languages and to most cultures.

Good pantuns often touch one's feelings, and more often than not they are universal in meaning and relevance. Furthermore, passionate and loyal poets and their audiences have nurtured them for many centuries, and inhabitants in many corners of the Archipelago accepted and owned, enriched and gave them wonderful variations them. They are so flexible that anyone can use and compose them in any language, dialect, and literary tradition. These are the qualities, among others, that allowed them to travel from Betawi (Jakarta) to Aceh, from Melaka to the Moluccas, from Makassar to Manado, and from Timor to Flores. They are the uniquely Nusantara (or Southeast Asian). 


\section{BIBLIOGRAPHY}

Abdullah, Arif. 1958. Pantōn aneuk miet. Djakarta: nn. [Panton Atjeh 1.]

Ahmad, Mohd Thani et al. 2002. Kurik kundi merah saga; Kumpulan pantun lisan Melayu. Kuala Lumpur: Dewan Bahasa dan Pustaka.

Andaya, Leonard Y. 2008. Leaves of the same tree; Trade and ethnicity in the Straits of Melaka. Honolulu: University of Hawai'i Press.

Angitong. 1899. Pantun perlawanan orang Panipi dan pantoen waktoe kedatangan Prins Frederik Hendrik di Ambon dan pantoen kapital Ambon serta lagi terhoeboeng pantoen sedikit pada menjoekakan hati. Np: Albrecht and Co.

Asfar, Dedy Ari. 2003. “Sastra lisan dan identitas pribumi Kalimantan Barat; Kajian di Lembah Sungai Sekadau dan Sungai Laur". [Manuscript.]

Collins, James. 2000. Malay, world language; A short history. Kuala Lumpur: Dewan Bahasa dan Pustaka.

Daillie, François-Rene. 2002. Alam pantun Melayu; Studies on the Malay pantun. Kuala Lumpur: Dewan Bahasa dan Pustaka, Ministry of Education.

Effendi, Chairil. 2009. "Oral tradition and identity of West Kalimantan society", Sari 27: 4-5.

Ganie, Tajuddin Noor. 2006. Jatidiri puisi rakyat etnis Banjar berbentuk peribahasa berbentuk puisi dalam jatidiri diri puisi rakyat etnis Banjar di Kalsel. Banjarmasin: Rumah Pustaka Folklor Banjar.

Hardjopradjoprawiro, Kunardi. 1985. Kajian bentuk dan lagu kidungan Jawa Timuran. [Yogyakarta]: Proyek Penelitian dan Pengkajian Kebudayaan Nusantara (Javanologi), Departemen Pendidikan dan Kebudayaan Derektorat Jenderal Kebudayaan.

Madjoindo, Aman B. Datuk. 1999. Kato Pusako; Pepatah, patitih, mamang, pantun, ajaran dan fisafat Minangkabau. Jakarta: Majelis Pembina Adat Alam Minangkabau, Rora Karya.

Masindan et al. 1987. Sastra lisan Melayu Langkat. Jakarta: Pusat Pembinaan dan Pengembangan Bahasa, Departemen Pendidikan dan Kebudayaan.

Munoz, Paul Michel. 2006. Early kingdoms of the Indonesian archipelago and the Malay Peninsula. Singapore: Didier Millet.

Munshi, Abdullah bin Abdul Kadir. 1838. Kesah pelayaran Abdullah. Singapore: Malaya Publishing House.

Nappu, Sahabudin and J.S. Sande. 1991. Pantun-pantun Makasar. Jakarta: Departemen Pendidikan dan Kebudayaan.

Piah, Harun Mat. 1989. Puisi Melayu tradisional; Satu pembicaraan genre dan fungsi. Kuala Lumpur: Dewan Bahasa dan Pustaka.

Piah, Harun Mat. 2001. Pantun Melayu bingkisan permata. Kuala Lumpur: Karyawan.

Ramli M.I. 2006. Tunggu Padi Jemoq; Serangkaian pantun Kedah. Edited by Muhammad Haji Salleh. Pulau Pinang: Penerbit Universiti Sains Malaysia.

Rusyana, Yus. 1984. Panyungsi sastra pengajaran sastra Sunda pikeun murid sakola lanjutan. Bandung: Gunung Larang.

Saldin, B.D.K. 2001. The Sri Lankan Malays and their language. Second edition. Colombo. 
Saleh, Nureeyan. 1999. Lagu Dodoi Melayu Patani. Bangi: Penerbit Universiti Kebangsaan Malaysia.

Salleh, Muhammad Haji. 2000. Puitika sastera Melayu. Kuala Lumpur: Dewan Bahasa dan Pustaka.

Salleh, Muhammad Haji and Bazrul Bahaman. 1999. “Sejarah kritis asal-usul, perkembangan, sebaran bentuk, estetika pantun Nusantara". [Manuscript.]

Sande, J.S. 1990. Sastra Toraja dan bahasa Melayu baku. Jakarta: Departemen Pendidikan dan Kebudayaan.

Silahuddin, Dharmawan Nur. 1990. Kumpulan pantun daerah Lahad. Palembang: Fakultas Keguruan dan Ilmu Pendidikan, Universitas Sriwijaya.

Skeat, Walter William. 1900. Malay magic being an introduction to the folklore and popular religion of the Malay Peninsula. London: Macmillan.

Sucianti. 1994. Pantun dalam sastera Enim sebagai sumbangan bagi pengajaran bahasa dan sastera Indonesia. Thesis, University of Muhammadiyah, Palembang.

Sunarti et al. 1978. Sastra lisan Banjar. Jakarta: Pusat Pembinaan dan Pengembangan Bahasa, Departemen Pendidikan dan Kebudayaan.

Tarigan, Henry Guntur and C. Jami Purba Tondang. 1980. Perbandingan umpasa Simalungun dengan pantun Melayu. Jakarta: Proyek Penerbitan Buku Sastra Indonesia dan Daerah, Departemen Pendidikan dan Kebudayaan.

Umar, Musni and Pudentia MPSS (eds). 2010. "Membangkitkan memori kolektif kesejarahan Malaysia-Indonesia". [Kertas kerja dialog.]

Umaruddin, H. 1995. "Adat istiadat Jambi". [Disampaikan pada mahasiswa IAIN Sultan Thaha Saifuddin Jambi yang akan melaksanakan KKN tahun 1995/1996 tanggal 25 Juli 1995 Jambi.]

Utomo, Bambang Budi and Nik Hassan Shuhaimi. 2008. Zaman klasik di Nusantara. Kuala Lumpur: Dewan Bahasa dan Pustaka.

Voisset, Georges. 1997. Histoire du Genre Pantoun: Malaisie, Francophonie, Universalie. Paris: Editions de L'Harmattan.

Winstedt, R.O. 1969. A history of classical Malay literature. Kuala Lumpur: Oxford University Press.

Wolters, O.W. 1982. History, culture, and religion in Southeast Asian perspectives. Singapore: ISEAS.

\section{ELECTRONIC SOURCES}

Alexander, A. 2007. "Muar wanyek, tradisi lisan Melayu Sambas dan Dayak Desa (Sebuah perbandingan); Oleh Sastra \& Seni Melayu Sambas", (http:// id-id.facebook.com/pages/ Sastra-Seni-Melayu-Sambas/301770551956), accessed 12 February 2011.

Gustaz,W,Petrusz. [nd]. "Pantun Melayu Kupang”, (http://www.geocities. ws/johnmanhitu2001/PANTUN_MELAYU_KUPANG_OM_GUSTAV. html), accessed 12 February 2011.

Harun, Jelani. [nd]. “Manuskrip 'Panthong' Sri Lanka”, (http://melayuonline. com/ind/article/read/214/manuskrip-panthong-dari-sri-lanka)., accessed 12 February 2011. 
Osup, Chemaline anak. 2006. "Leka main; Puisi rakyat Iban - Satu analisis bentuk dan fungsi", (http://eprints.usm.my/9122/1/LEKA_MAIN_ PUISI_RAKYAT_IBAN_-_SATU_ANALISIS.pdf), accessed 19 February 2011.

Saharuddin, Inon. 2002. "Three singers; The keepers of traditions", (http:/ / www. aseancultureand information. org/coci/files/Malaysia/ Malaysia\%20-\%20THREE\% 20SINGERS.pdf), accessed 12 February 2011. 